\title{
The Threshold Effects of Current Account Deficits on Economic Growth in Turkey: Does the Level of Current Account Deficit Matter?
}

\author{
Celil Aydın and Ömer Esen
}

\begin{abstract}
This paper investigates the existence of the threshold effects of current account deficits on economic growth over the period of 1999:Q2 - 2014:Q2 for Turkey by using recently developed threshold autoregressive (TAR) models that provide appropriate procedures for estimation and inference. Based on the estimation of the threshold model, the results reveal evidence of threshold effects related to the current account deficits in Turkey. According to the analysis results, the estimated threshold value of the deficits for economic growth is $4 \%$, and any ratio of the current account deficits above this threshold has a negative effect on economic growth while any rate below this threshold has a positive effect on economic growth. The findings may contribute to political authorities and decision-makers as a guide for economic and political targeting in terms of keeping the deficit rate below the threshold level of $4 \%$ to prevent its negative effect on economic growth.
\end{abstract}

Index Terms-Economic growth, current account deficit, nonlinearity, threshold autoregressive model.

\section{INTRODUCTION}

The phenomena of foreign trade and economic growth, which have taken an important place on the grounds of economic approaches that have followed one another throughout the historical development of economy, have been among the most debated and searched topics in all periods of economic life. A healthy functioning of economic life and a sustainable maintenance of economic balances depend, above all, on the regular and stable structure of macroeconomic variables that constitute the general economic structure. Balanced growth, which is defined in the literature as growth by paying regard to internal balance (saving-investment balance and budget balance) and external balance (current account balance), is the ultimate goal of economies, developing economies being in the first place.

With economic growth, developing countries wish to raise standard of living to the level of develop countries in a rapid way. While developing countries are accelerating the growth process, they are faced with a dilemma: maintaining a fast and steady growth on one hand and having the resources needed for this development on the other hand. Due to such dilemma, countries have two options: "being satisfied with low growth through production based on the available internal resources" or " increasing growth by compensating for the missing part

Manuscript received March 29, 2016; revised August 8, 2016

The authors are with Faculty of Economics and Administrative Sciences, Department of Economics, Muş Alparslan University Muş, Turkey (e-mail: celil.aydin@atauni.edu.tr, o.esen@alparslan.edu.tr). of needed resources through external purchase". Choosing the growth strategy of any of these two options has limitations and risks. The limitedness of internal resources and the existence of the risk posed by the use of external resources make it obligatory to evaluate internal balance and external balance together and adopt an optimal current account balance for a sustainable growth. Accordingly, countries need to increase their total production volume (GDP) to display a continuous and growing performance. It is natural that need for technology, intermediate goods, and investment goods increases as a result of increased production. As a matter of fact, one of the most evident reasons for the problems encountered in the growth performances of underdeveloped or developing economies is inadequacy of technology, intermediate goods, and investment goods [1]. Countries firstly attempt to reach the level of production required for a steady and sustainable economic growth by using their own internal dynamics. However, today a considerable number of developing countries cannot obtain adequate intermediate goods and investment goods to reach the level of production needed for growth from their domestic markets. As a result, adequate production cannot be made to provide capital accumulation in those economies which fail to have resources at sufficient level. Therefore, a desired rise cannot be achieved in national income. In this case, import of intermediate goods and investment goods, which are used as an input for production, becomes necessary to achieve and sustain economic growth [2]. Accordingly, obtaining intermediate goods, investment goods, and new technologies that are not produced at all or are produced relatively little inside the country through import plays a critical role in ensuring sustainable growth by supporting domestic production and promoting the level of investment. Import is of great importance to make and sustain production within a structure of production based on imported input. However, inadequacy of domestic resources and technology causes economic growth to depend on external resources, and the rapid growth, which is desired in the growth process, leads to a deficit in current account [3]. The growth efforts of countries bring along a deficit in current account [4]. Moreover, failure in meeting the cost of technology transfer and the import of intermediate goods and investment goods with export revenue makes current account deficit permanent. Current account deficit is regarded as one of the important reasons for unsteady growth especially in developing countries. Thus, the controllability of current account deficit and the selection of policies to be implemented play a determining role on economic growth performance. 
Current account balance, which constitutes an important part of balance of payments reflecting the economic and financial relations of a country with the rest of the world according to what is reported in economics literature, is considered an indicator of the course of economy. Hence, it has a determining role on economic decisions and expectations [5]. Any deficit in this area means that a country invests more than its savings or spends more than it produces. This situation, which increases the need of a country for external debt, negatively affects growth rate in those periods when problems are encountered in taking on external debt (due to inconvenient redemption date [term of payment] and interest rate options, etc.). Therefore, current account deficit poses a threat to macroeconomic stability and balanced growth. The main problem at this point is the financing and sustainability of current account deficit rather than increase in it [2]. It can be said that financing current account deficit through direct investments or inflow of foreign currency extended over a long period of time is relatively less problematic or risky. On the other hand, financing current account deficit through speculative short-term and external debt-increasing hot money inflow may pose a big danger for economy. The foreign capital used in financing the deficit may not show tolerance towards a country which consumes more than it produces when a specific threshold is exceeded. When the deficit is perceived not to be sustainable anymore, an exact opposite process may start, and capital outflow may begin. [6] expresses this situation as follows: when markets think that the debts of a country are no longer sustainable, payment problem and exchange rate crisis may come out. As a result, a rapid fall may occur in the international reserves of the country and a crisis may emerge. [7] regard current account deficit as an indicator of a looming crisis and suggests that if anticipated current account deficit is large or a country with a foreign borrowing does not have enough current account surplus, such country leaves itself wide open to devaluation (crisis). Contrary to this, [8] emphasize in their empirical research that a specific threshold of current account deficit is not a sufficiently informative indicator for sustainability. They argue that the sustainability of current account deficit must be evaluated by considering other structural macroeconomic factors. In the same way, [9] stated that current account balance is in continuous interaction with macroeconomic variables and thus it might be quite difficult and misleading to determine a sustainable threshold. In this sense, when the previous experiences are considered, it is clear that a country having current account deficit does not necessarily experience a crisis. However, it is seen that current account deficit is an important trigger of economic crises, depending on the size of the deficit, for countries which have difficulty in financing their current account deficit or do not choose strong or reliable financial sources even if they can finance their current account deficit [10]. Some economists such as [11], [12] say that current account deficit plays an important role in the crises experienced. [9] treats the size of current account deficit in a country as a leading indicator of a potential economic crisis that may emerge in future periods and mentions that a persistent large-scale current account deficit is a significant economic problem and may lead to bigger problems unless necessary precautions are taken. The previous economic crisis experiences imply that a current account deficit of 4\% [13] to 5\% [14]-[16] of GDP is sustainable, though it is not an adequate criterion for the evaluation of sustainability by itself, and exceeding these rates may be taken as the signs of a crisis. In this regard, macroeconomic stability and sustainable growth largely depend on taking current account deficit under control and making the items used for financing sounder. Increase in current account deficit and deterioration of financing quality is important risk factors for an economy and may tarnish the confidence in the investment environment of a country. In this respect, the position current account gets is very important for a sustainable economic stability.

The relationship between economic growth and current account deficit in Turkey largely results from using imported input of high amount in the production process (i.e. following an import-based growth process). Turkey, which is poor in energy resources, compensates for its energy need through imported energy inputs by necessity. This necessity increases the import of energy products, which have a considerable share in the growth in current account deficit (the share of imported energy inputs in total import is $25 \%$ according to 2012 data), and the amount of payments made for their import. That causes current account balance to have deficit continuously as a result of energy import. Turkey has gone through a lot of crises with its persistent current account deficit. It is generally accepted that one of the most important reasons for the crises in 1994 and 2001 was that current account deficit to GDP ratio exceeded a specific critical threshold (3.5\%-4\%) [17]. Hence, this level has been accepted by market participants as a threshold for a sustainable current account deficit. After all these developments, a lot of economists and analysts emphasize that current account deficit should be monitored carefully, and persistent and high current account deficits have an important effect on economic stagnation.

It is observed in the literature that most of the research exploring the relationship between current account deficit and economic growth focuses on the models and analyses based on linearity hypothesis. In the analyses and comments made based on the hypothesis that the relationship is linear, it is suggested that the effect of current account deficit on growth develops symmetrically in those periods in which it increases or in those periods in which it decreases. However, in practice, it is seen that not every country having current account deficit experiences a crisis and even that some countries which have a low current account deficit go through a crisis frequently. Such an asymmetry has a nonlinear character. Previous empirical research informs little about whether the relationship is linear (i.e. whether current account deficit has a threshold). The present study aims to investigate the relationship between current account deficit, which is accepted as a crisis indicator for Turkey, and economic growth. A threshold regression model was used to determine the level at which current account deficit starts to have a negative effect on growth in Turkey. In this way, it is considered that it will make a positive contribution to the literature that explores the foundations of the economic development in Turkey. In addition, an attempt was made to contribute to grounding current account deficit-growth 
discussions in Turkey, which are mostly maintained based on wrong theoretical and empirical assumptions, on a sound basis. Above, the effect of current account deficit on growth, the sustainability of current account deficit, and whether there is any threshold for current account deficit have been discussed within the framework of different economic views. Below, theoretical and empirical literature on the relationship between current account deficit and growth will be presented in the first place. Then the interaction between current account deficit and growth in Turkey between 1999:Q2 and 2014:Q2 and whether there is a threshold where current account deficit begins to be unsustainable will be investigated Finally, the consistency of the obtained findings with the existing literature will be evaluated.

\section{LITERATURE REVIEW}

Discussions on current account deficit mostly center on its sustainability. Recently, these discussions have rapidly increased especially in developing countries, and a lot of studies have been carried out on this subject. The most important result found in these studies is that current account deficit varies from country to country and is connected with the fragility and crisis susceptibility of the economy of a country. In the literature, generally, empirical attempts are made to determine the degree to what current account deficit and its size, besides other macroeconomic variables, is influential on economic growth (especially on economic crises).

Majority of the studies carried out so far have focused on the relationship between the two variables, but have provided little information about whether current account deficits have any threshold. According to the analysis results of [9], though empirical findings vary by the group of countries addressed and the definition of crisis, increase in current account deficit raises the possibility of a crisis in the group of developing countries except for Africa. When all groups of country are included in the analysis, results vary by the definition of crisis. [9] concluded that while increase in current account deficit affects crises that have a broad definition, it does not have any statistical effect on crises that have a narrow definition. Analyzing whether there is any threshold of current account in developed countries, Freund (2005) divided the time period he examined into 25 episodes and revealed the current account deficit dynamics in these episodes. He found out that when the current account deficit to GDP ratio reaches 5\%, adjustment process starts and after this point it reverses and tends to decrease. He states that it will result in slow income growth and considerable real exchange rate depreciation in a 3 - to 4-year process. However, he emphasized that there are serious differences between countries in terms of the threshold of current account deficit. [18] conducted a similar study and explored the relationship between current account balance and economic growth for developed countries by dividing the period between 1980 and 2003 into 26 episodes. They concluded that increase in current account deficit has a negative effect on economic growth. Conducting a similar study for Turkey, [19] regard increased current account deficit as an important element of risk for economy. They examined the sustainable CAD/GNP level in the medium and long term and determined threshold as $3.6 \%$ for the moderate scenario and as 5.5 to $6 \%$ for the good scenario. They state that if these thresholds are exceeded in Turkey, fragility against financial turbulences to be caused by negative shocks can increase. [20] carried out a study for early warning system for crises based on the data of 174 countries from the 1980 to 2008 period and concluded that high current account deficit increases the risk of crisis for the countries under examination.

\section{THEORETICAL MODEL}

To investigate the relationship between current account deficit and economic growth, a growth model was created based on the models employed by [21], [22], and [23]. This model is demonstrated in Equation 1;

$$
\dot{Y}=\delta_{0}+\delta_{1}\left(\frac{I_{t}}{Y_{t}}\right)+\delta_{2} \dot{L}_{t}+\delta_{3} C A B_{t}+\delta_{4} z_{t}+e_{t}
$$

In equation (1), $\dot{Y}$ indicates the growth rate of real GDP at $t$ time; $I_{t} / Y_{t}$ indicates private gross fixed capital formation as a share of GDP at $t$ time; $\dot{L}_{t}$ indicates labor force growth rate at $t$ time; $C A B_{t}$ indicates current account at $t$ time; $z_{t}$ indicates control variables; and $e_{t}$ indicates white noise error term.

To control the effects of other macroeconomic variables connected with current account on economic growth, percentage change in the terms of trade, openness, and percentage change of the CPI index were used as control variables based on [24]-[26].

\section{ECONOMETRIC METHODOLOGY}

The In developing countries, inadequacy of internal resources and technology causes growth to depend on external resources while the rapid growth targeted in the development process leads to current account deficit. Thus, current account deficit becomes one of the most important sources of economic growth on one hand and increases fragility against external shocks by exposing economies to risks such as a considerable amount of capital outflow and foreign exchange bottleneck on the other hand. Current account deficit and the bigness of such deficit negatively affect expectations and play a determining role on the crisis expectations of market actors. Increase in crisis expectations, on the other hand, poses a threat to macroeconomic stability and balanced growth. In economies, problems such as economic or political crises emerging in domestic and foreign markets lead to breaks in time series [27]. Breaks may bring about a nonlinear structure in econometric models. That has led to the development of nonlinear models that can represent regime switches (shifts) and estimation methods for these models.

One of the most frequently used methods in estimation of nonlinear models is the Threshold Autoregressive Model (TAR) which was proposed by [28] and developed by [29][32]. The basic feature of this model is its determination of one or more threshold values, thus allowing the estimation of 
different linear models for different regimes. In this model, the value that indicates the regime switching is threshold, while the variable causing the regime switching is called threshold variable.

The linear model derived from the Equation (1) provides a structure for estimating the impact of current account deficit on economic growth, but it does not give us information about how the changes in current account deficit affect the relationship between the two variables. This indicates the existence of a nonlinear relationship between economic growth and current account deficit. The TAR model is one of the approaches used in estimating a nonlinear relationship. It allows determining the existence of nonlinear relationship between the two variables and revealing the differences in the effect of this relationship on economic growth, if any.

Equation (2) is the two-regime Threshold Autoregressive (TAR) model that estimates a nonlinear relationship between economic growth and government spending:

$$
\begin{aligned}
& \dot{Y}_{t}=\alpha_{0}+\sum_{i=1}^{p} \alpha_{i} \dot{Y}_{t-i}+\varepsilon_{1 t} \text { if }\left[s_{t-d} \leq \theta\right] \\
& \dot{Y}_{t}=\beta_{0}+\sum_{i=1}^{p} \alpha \beta_{i} \dot{Y}_{t-i}+\varepsilon_{2 t} \text { if }\left[s_{t-d}>\theta\right]
\end{aligned}
$$

where $\dot{Y}_{t}$ is the dependent variable, $s_{t-d}$ is the threshold variable causing the regime switching, $\theta$ is the threshold value, $d$ is the delay parameter, $p$ is the proper delay time and $\varepsilon_{1 t}$ and $\varepsilon_{2 t}$ are independent and identically distributed random error terms. $s_{t-d} \leq \theta$ follows an autoregressive process with parameters $\alpha_{0}$ and $\alpha_{i}$, while $s_{t-d}>\theta$ follows a different autoregressive process with $\beta_{0}$ and $\beta_{i}$. The linear model Equation (1) which estimates the effect of current account deficit on economic growth can be transformed into a two-regime TAR model and expressed as in Equation (3) as follows:

$$
\begin{aligned}
& \text { Growth }_{t}=\left(\begin{array}{l}
\delta_{10}+\delta_{11} \text { InvGr }_{t}+\delta_{12} \text { LabGr }_{t}+\delta_{13} \text { Tot }_{t} \\
+\delta_{14} \text { Open }_{t}+\delta_{15} \pi_{t}+\delta_{16} C A B_{t}
\end{array}\right) I\left[C A B_{t-d} \leq \theta\right] \\
& +\left(\begin{array}{l}
\delta_{20}+\delta_{21} \text { InvGr }_{t}+\delta_{22} \text { LabGr }_{t}+\delta_{23} \text { Tot }_{t} \\
+\delta_{24} \text { Open }_{t}+\delta_{25} \pi_{t}+\delta_{26} C A B_{t}
\end{array}\right) I\left[C A B_{t-d}>\theta\right]
\end{aligned}
$$

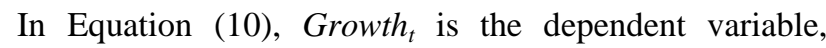
$\delta_{10}$ and $\delta_{20}$ are constant parameters, InvGr,$L a b G r_{t}$, Tot $t_{t}$, and Open $_{t}$ are control variables, $I_{t}(\theta)$ is the indicator function and $\varepsilon_{t}$ is the independent and identically distributed random error term. The indicator function is $I=1$ where $I_{t}(\theta)=\left[C A B_{t-d} \leq \theta\right], \mathscr{C} A B_{t-d} \leq \theta$, and $I=0$ otherwise.

In transforming the linear model into a TAR model, Akaike or Schwarz information criterion is used to select the proper delay time $(p)$ of the threshold value for the linear AR model. Then the delay parameter $(d)$ is selected through a nonlinearity testing separately conducted for each delay and the rejection of the null hypothesis of nonlinearity. Then the threshold number and threshold values are determined. Finally, different linear models are constructed for different regimes and the models are estimated [27].
The linearity test is conducted by using the statistic $F(p, d)$ that follows an $F$ distribution. Following is the equation (4) to compute the statistic $F(p, d)$ :

$$
F(p, d)=\frac{\left(\sum \varepsilon_{t}^{2}-\sum \varepsilon_{t}^{2}\right) /(p+1)}{\sum \varepsilon_{t}^{2} /(n-d-b-p-h)}
$$

In the Equation (4), $\varepsilon_{t}^{2}$ indicates the residual sum of squares (RSS) obtained by using recursive least squares from the autoregressive process arranged as $\operatorname{AR}(p)$ for the observation $n$, while $\varepsilon_{t}^{2}$ is the RSS derived from the linear regression model by using least squares. $p$ indicates the proper delay and $d$ indicates the delay parameter. $b$ and $h$ are computed via $b=(n / 10)+p$ and $h=p+1-d$ [32]. In testing the existence of threshold value, likelihood ratio $(L R)$ and bootstrap method are used since the threshold value is unknown [30]. Equality of coefficients across different regimes in LR testing is tested under a null hypothesis $H_{0}: \alpha_{i}=\beta_{i}$ ? $i=\ldots p$ of no threshold effect for Equation (2).

$$
L R_{1}=\frac{\sigma_{0}-\sigma_{1}(\theta)}{\sigma^{2}}
$$

In the Equation (5), $\sigma_{0}$ and $\sigma_{1}$ are RSS values estimated under the null hypothesis $\left(H_{0}\right)$ and the alternative hypothesis $\left(H_{a}\right)$, respectively. $\sigma^{2}$ indicates the variance of error terms. In cases of rejection of the null hypothesis, the new hypothesis for threshold value is $H_{0}: \theta=\theta_{0}$ and the likelihood statistics $L R_{l}$ in Equation (5) turns into the one in Equation (6):

$$
L R_{2}=\frac{\sigma_{1}(\theta)-\sigma_{1}(\theta)}{\sigma_{1}(\theta)}
$$

In Equation (6), the threshold value $(\theta)$ is estimated by using ordinary least squares (OLS) and the optimal threshold value is computed via $\theta=\operatorname{argmin}_{1}(\theta)$ [30]. After determining the threshold value, the appropriate TAR model is constructed.

\section{DATA}

This study aims to reveal the relationship between current account deficit and economic growth in Turkey based on the quarterly data of the period from 1999:Q2 to 2014:Q2. To this end, GDP growth rate (growth) is used to measure the growth rate. The share of total current account balance in the GDP $(C A B)$ was determined as the independent variable of the model. To control the effect of other macroeconomic variables, along with current account deficit, on economic growth, growth rate of gross domestic fixed capital formation (InvGr), growth rate of employed population ( $L a b G r)$, percentage change in the terms of trade (Tot), openness (Open), and percentage change of the CPI index $(\pi)$ were taken as control variables. 
Data concerning the terms of trade and openness were obtained from the data delivery system of the CBRT. Data concerning other variables were obtained from the Federal Reserve System (FED). To eliminate seasonality from the data, the growth rates concerning the variables were calculated in a way to reflect the changes compared to the corresponding quarter of the previous year. Table I shows the basic information about the variables.

TABLE I: BASIC INFORMATION ABOUT THE VARIABLES

\begin{tabular}{ll}
\hline \hline Variable & \multicolumn{1}{c}{ Explanation } \\
\hline Growth & Annual growth rate of Gross Domestic Product (GDP) \\
$I n v G r$ & Annual growth rate of Gross Domestic Fixed Capital Formation \\
LabGr & Annual growth rate of Employed Population (Aged 15 and Over) \\
ToT & The annual percentage change in the terms of trade, where the terms of trade are measured as exports divided \\
Open & by imports \\
$\pi$ & The share of exports plus imports in the GDP \\
$C A B$ & The annual percentage change of the CPI index \\
\hline \hline
\end{tabular}

TABLE II: DESCRIPTIVE STATISTICS

\begin{tabular}{cccccccc}
\hline & Growth & InvGr & LabGr & ToT & Open & $\pi$ & CAB \\
\hline Mean & 0.084 & 6.379 & 0.072 & 1.354 & 3.419 & 7.924 & -4.253 \\
Maximum & 10.562 & 44.230 & 7.628 & 64.409 & 4.264 & 17.628 & 4.534 \\
Minimum & -8.398 & -40.526 & -8.810 & -26.376 & 3.108 & 4.148 & -10.020 \\
Std. deviation & 3.615 & 19.249 & 2.609 & 17.588 & 0.250 & 2.898 & 3.041 \\
Skewness & 0.209 & -0.246 & -0.229 & 1.753 & 1.655 & 1.126 & 0.384 \\
Kurtosis & 3.542 & 2.895 & 5.028 & 7.320 & 5.215 & 4.175 \\
Jarque Bera p-value & 0.551 & 0.725 & 0.004 & 0.000 & 0.000 & 0.000 & 0.455 \\
\hline
\end{tabular}

\section{ESTIMATION RESULTS}

\section{A. Testing the Presence of Government Spending Threshold Effect}

The analysis starts with the calculation of some statistics concerning the variables used in the model. The obtained results are given in the Table II.

As it is seen in the Table II, the highest value of the share of total current account balance in the GDP is approximately $4.53 \%$, and its lowest value is $-10.02 \%$. The mean value of the share of total current account balance in the GDP is $-4.25 \%$.

The correlation matrix concerning the explanatory variables used in the model is indicated in Table III. According to the correlation matrix, the highest correlation (0.514) is between $C A B$ and $T o T$ while the lowest correlation
(-0.798) is between ToT and InvGr. Considering other correlation coefficients, they vary between -0.459 and 0.370 . This implies a lack of multicollinearity problem between the explanatory variables.

Dickey-Fuller (1979) stationary testing was conducted to show that the variables used in the model were stationary at level. The testing results are presented in Table IV. According to the Dickey-Fuller (1979) test statistics, all the variables used in the model are stationary.

After the variables were found to be stationary, the approach proposed by [32] as used to reveal the nonlinear structure between current account deficit and economic growth. Table V shows the results of the linearity test for each current account deficit lag depending on different delay parameters.

TABLE III: CORRELATION MATRIX

\begin{tabular}{ccccccc}
\hline & InvGr & LabGr & Tot & Open & $\pi$ & CAB \\
\hline InvGr & 1.000 & & & & & \\
LabGr & 0.197 & 1.000 & & & & \\
ToT & -0.798 & -0.200 & 1.000 & & & \\
Open & -0.093 & 0.060 & -0.150 & 1.000 & & \\
$\pi$ & -0.276 & -0.137 & 0.350 & -0.336 & 1.000 & \\
CAB & -0.459 & -0.001 & 0.514 & 0.118 & 0.370 & 1.000 \\
\hline
\end{tabular}

TABLE IV: UNIT RoOT TEST RESULTS

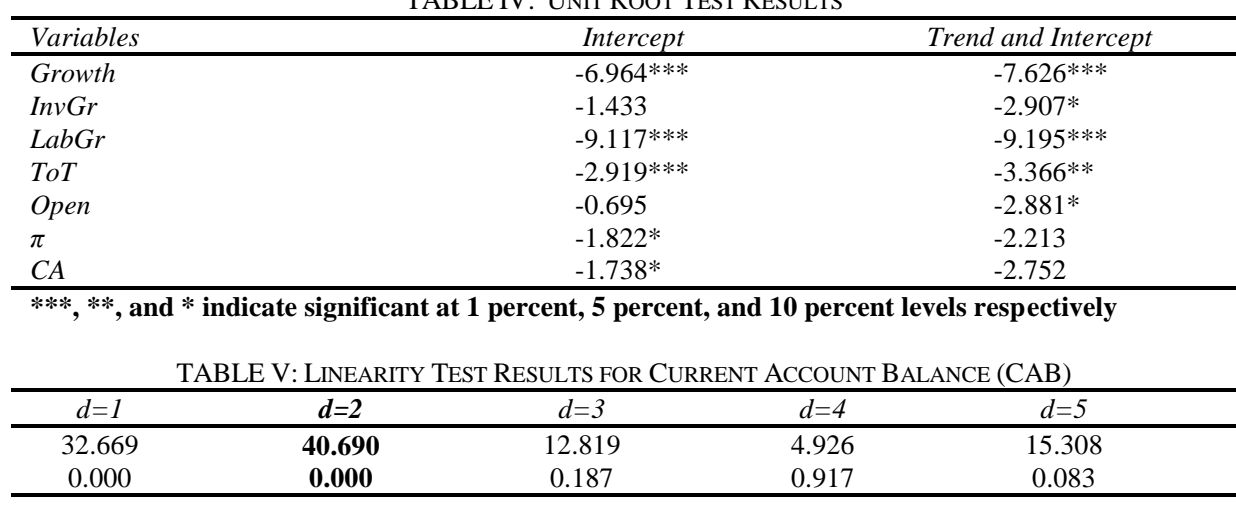

According to the probability and f-statistic values given in the Table $\mathrm{V}$, linearity was most strongly rejected for $C A B$ in 
the second delay. Therefore, the delay parameter $(d)$ for $C A B$ was determined to be 2 . The findings show that current account deficit implies a regime switching two periods in advance. In that case, the threshold value for current account deficit is $C A B_{t-2}$.

The next step of the analysis was to find out whether there was a threshold value causing regime switch in the series concerning current account deficit, and if so, to determine the threshold number and value. The approach proposed by [28] and [30] was used in determining and estimating the threshold value leading to regime switching. The $L R$ statistics estimated via RATS 8.0 and Matlab 7.0.4 as well as the threshold value concerning these statistics are presented in Table VI for $C A B_{t-2}$. LR statistics were obtained using 5000 bootstrap replications.

TABLE VI: THRESHOLD TEST RESULTS

\begin{tabular}{lccc}
\hline & TABLE VI: THRESHOLD TEST RESULTS & \\
\hline Threshold variable: $\left(\boldsymbol{C A B}_{\boldsymbol{t}-2}\right)$ & $\begin{array}{c}\text { Threshold value } \\
(\% \text { GDP })\end{array}$ & $\begin{array}{c}\text { Confidence Interval } \\
\text { LR Stat }\end{array}$ & $\begin{array}{c}\text { Bootstrap } \\
\mathrm{p}-\mathrm{value}\end{array}$ \\
\hline 1st threshold $\left(H_{0}^{1}:\right.$ Nothreshold value exists $)$ & $-3.99 \%$ & {$[-5.17 \%,-3.13 \%]$} & 40.690 \\
2nd threshold $\left(H_{0}^{2}:\right.$ A?threshold value exists $)$ & - & 0.000 & 5.762 \\
\hline
\end{tabular}

TABLE VII: REGRESSION RESULTS (DEPENDENT VARIABLE: GROWTH)

\begin{tabular}{|c|c|c|c|}
\hline Threshold value $\left(C A B_{t-2}\right)$ & Linear model & $\begin{array}{c}\text { Regime (1) } \\
<=3.99 \%\end{array}$ & $\begin{array}{c}\text { Regime (2) } \\
>3.99 \% \\
\end{array}$ \\
\hline $\operatorname{InvGr}$ & $\begin{array}{l}-0.039 \\
(0.037)\end{array}$ & $\begin{array}{l}0.086^{*} \\
(0.045)\end{array}$ & $\begin{array}{l}-0.080^{*} \\
(0.041)\end{array}$ \\
\hline$L a b G r$ & $\begin{array}{l}0.143 \\
(0.901)\end{array}$ & $\begin{array}{l}-0.026 \\
(0.177)\end{array}$ & $\begin{array}{l}0.262 \\
(0.186)\end{array}$ \\
\hline ToT & $\begin{array}{l}-0.147 * * * \\
(0.043)\end{array}$ & $\begin{array}{l}0.099 \\
(0.069)\end{array}$ & $\begin{array}{l}-0.185 * * * \\
(0.049)\end{array}$ \\
\hline Open & $\begin{array}{l}-2.059 \\
(1.938)\end{array}$ & $\begin{array}{l}0.294 \\
(3.133)\end{array}$ & $\begin{array}{l}-2.525 \\
(2.168)\end{array}$ \\
\hline$\pi$ & $\begin{array}{l}0.088 \\
(0.166)\end{array}$ & $\begin{array}{l}-0.153 \\
(0.318)\end{array}$ & $\begin{array}{l}-0.512^{*} \\
(0.257)\end{array}$ \\
\hline$C A B$ & $\begin{array}{l}0.341 * * \\
(0.169)\end{array}$ & $\begin{array}{l}-0.678^{* *} \\
(0.269)\end{array}$ & $\begin{array}{l}1.759 * * \\
(0.661)\end{array}$ \\
\hline Constant & $\begin{array}{l}8.316 \\
(7.652)\end{array}$ & $\begin{array}{l}-5.887 \\
(11.691) \\
\end{array}$ & $\begin{array}{l}19.825^{* * *} \\
(8.812)\end{array}$ \\
\hline $\begin{array}{l}\text { Obs. } \\
\mathrm{R}^{2}\end{array}$ & $\begin{array}{l}61 \\
0.25\end{array}$ & $\begin{array}{l}34 \\
0.43\end{array}$ & $\begin{array}{l}25 \\
0.49\end{array}$ \\
\hline
\end{tabular}

According to the Table VI, for current account deficit, delay parameter was found to be $d=2 ; L R$ statistic was found to be 40.690; and bootstrap probability value was found to be 0.000 . At the $5 \%$ significance level, the null hypothesis $H_{0}^{1}$ hat the series has no threshold value was rejected for current account deficit. Another hypothesis was constructed to test the existence of a second threshold value. $L R$ statistic was found to be 5.762, and bootstrap probability value was found to be 0.212 . At the $5 \%$ significance level, the null hypothesis $H_{0}^{2}$ that the series has a threshold value was not rejected, and it was concluded that the series had one threshold effect. At the end of the analysis, the relationship between current account deficit and economic growth was found to be nonlinear, and the threshold value was found to be $3.99 \%$ for current account deficit. In addition, while the lower limit is $-5.17 \%$ for the threshold value at the $95 \%$ confidence level, the upper limit is $3.13 \%$ for it. This finding of the study is consistent with the current account levels suggested for developing countries by [13] (4\%); [14], [15], and [16] (5\%); and [17] (3.5\% to 4\%).

\section{B. The Relationship between Current Account Deficit and Economic Growth}

The TAR model was estimated to determine whether the effect of current account deficit on economic growth differs above and below the threshold and to find out the direction of the effect. The TAR model indicting the current account deficit-economic growth relationship below the threshold was obtained by using the Equation (3).

Table VII shows the results of the two-regime TAR model used to reveal the relationship between economic growth and current account deficit below the threshold.

The linear model given in the Table VII shows the linear relationship between current account deficit and economic growth, while the regime 1 and 2 show the current account deficit-economic growth relationship when current account balance is below and above the threshold respectively. The results of the linear model show that there is a statistically significant and positive relationship (at the 5\% significance level) between current account deficit and economic growth. According to the regime 1 which shows the case where current account balance is below the threshold, there is a statistically significant (at the 5\% significance level) and positive relationship between current account deficit and economic growth when current account deficit to GDP ratio is below $3.99 \%$. According to the regime 2 which shows the case where current account deficit to GDP ratio is above $3.99 \%$, there is a statistically significant (at the $5 \%$ significance level) but negative relationship between current account deficit and economic growth. In other words, while a current account deficit level below the threshold value positively affects economic growth, a current account deficit level above the threshold value negatively affects it. Also, when the regime coefficients are compared, it is seen that the effect of current account deficit on economic growth is 
stronger in the regime in which it is below the threshold value.

Additionally, according to the linear model results, there is a statistically insignificant and negative relationship between growth rate of gross domestic fixed capital formation and economic growth. While this relationship is statistically significant and positive below the threshold value, it is statistically significant and negative above the threshold value. The negative value of the growth rate of gross domestic fixed capital formation in the regime 2 can be attributed to the dependency of export and manufacturing industry in Turkey on the import of raw material and energy. Decrease in imported goods and services needed for manufacturing as a result of fall in current account deficit may lead to a reduction in investment and thus production. On the other hand, when the coefficients of the growth rate of gross domestic fixed capital formation in both regimes are compared, it is seen that the effect of growth rate of gross domestic fixed capital formation on economic growth is the same in both regimes.

The findings regarding the estimated models can be summarized as follows: a) The analysis of the period of 1999:Q2-2014:Q2 shows that the regime switches in the series regarding current account deficit can be predicted two periods in advance. In other words, any change in current account deficit gives an indication two periods beforehand. b) The findings show that there is a nonlinear relationship between current account deficit and economic growth; the relationship follows a one-threshold and two-regime process; the effect varies above and below the threshold; the effect of current account balance on economic growth is significant and positive when it is below the threshold and is significant and negative when it is above the threshold.

\section{CONCLUSION}

Developing countries like Turkey obtain the technology, intermediate goods, and investments goods needed in the development process through import to a considerable extent. Though the import of technology, intermediate goods, and investment goods which cannot be obtained from the domestic market is necessary for the development of these countries, it causes production and export to depend on import. Moreover, when import cannot be met by export revenues, the problem of current account deficit emerges. A lot of developing countries, Turkey being in the first place, are faced with current account deficit and the problem of financing such deficit. Exploration of the size and sustainability of current account deficit in Turkey, which is inevitable due to the above-mentioned reasons, as well as whether it has a threshold value may make an important contribution to the selection of policies to be implemented for current account deficit and to the growth process.

Most of the research in the literature focusing on the relationship between current account deficit and economic growth involves the models created based on the hypothesis of linearity as well as causality, cointegration, or panel data analyses. The analyses and comments made based on the hypothesis of the linearity of the relationship assume that the absolute effect of current account deficit on growth is the same in all periods when it increases or in all periods when it decreases (i.e. the relationship is symmetrical). However, in practice, it is seen that not every country having current account deficit experiences a crisis and even that some countries which have a low current account deficit go through a crisis frequently. Such an asymmetry has a nonlinear character. In this regard, this study made an attempt to determine whether there has been a nonlinear relationship between current account deficit and economic growth in recent years contrary to what is believed and, if so, whether this nonlinear relationship is true for Turkey. Analyses were made based on the quarterly data from the period between 1999:Q2 and 2014:Q2. The analysis started with the examination of the relationship between quarterly growth rate of GDP and current account deficit; the series which were determined to be stationary were found to be nonlinear; and only one threshold was determined for current account deficit at the end of the testing conducted by the approach proposed by [28]-[30]. Then an appropriate TAR model was created for current account balance, and the models were estimated. Threshold value for current account deficit was found to be $3.99 \%$ for the entire analysis period. It was determined that the relationship between current account deficit and economic growth differed by the position relative to the threshold value (i.e. below the threshold value or above the threshold value). It was seen that a current account deficit below the threshold value had a statistically significant and positive effect on economic growth while a current account deficit above the threshold value had a statistically significant and negative effect on it.

The findings of this study demonstrate that current account deficit in Turkey has a particular threshold value; current account deficit is an important obstacle to economic growth when such threshold is exceeded; and current account deficit has to be kept under control for a balanced and sustainable growth performance. However, it should be noted that though the threshold level calculated for current account deficit is an important indicator for economic growth, it may not represent the sustainability of current account deficit, which is in continuous interaction with economic and political stability as well as a lot of macroeconomic variables such as exchange rate policy implemented, openness ratio, domestic investment-savings level, price stability, and the structure of the financial system. That reveals that the position current account gets is very important for a sustainable economic stability, but it must be evaluated by considering other factors, too.

\section{REFERENCES}

[1] S. İnançlı and A. Konak, "The dependency of import to the export in Turkey: An example of automotive sector," Eskisehir Osmangazi University Journal of Economics and Administrative Sciences, vol. 6, no. 2, pp. 343-362, 2011.

[2] M. Cural, "Process and financing of current account balance in developing counties post 1980," Marmara University Journal of Economic and Administrative Sciences, vol. 29, no. 2, pp. 173-195, 2010.

[3] Y. Bayraktutan and I. Demirtaş, "Main determiners of current deficits in developing countries: A panel data analysis," Kocaeli University Journal of Social Sciences, no. 22, pp. 1-28, 2011.

[4] C. A. Calderon, A. Chong, and N. V. Loayza, "Determinants of current account deficits in developing countries," Contributions to Macroeconomics, vol. 2, no. 1, pp. 1-31, 2002.

[5] M. Eğilmez and E. Kumcu, Economic Policy: Theory and Practice in Turkey, Istanbul: Remzi Publishing, 2011. 
[6] S. Fischer, "Financial crises and reform of the international financial system," Review of World Economics, vol. 139, no. 1, pp. 1-37, 2003.

[7] S. Fischer, "Real balances, the exchange rate, and indexation: Real variables in disinflation," The Quarterly Journal of Economics, vol. 103, no. 1, pp. 27-49, 1988.

[8] G. M. Milesi-Ferretti and A. Razin, "Sustainability of persistent current account deficits," National Bureau of Economic Research, NBER Working Paper 5467, 1996.

[9] S. Edwards, "Does the current account matter?" in Preventing Currency Crises in Emerging Markets, S. Edwards and J. A. Frankel, Eds., The University of Chicago Press, 2002, pp. 21-69.

[10] S. Erdoğan and H. Bozkurt, "The determinants of current account deficit in Turkey: An analysis with MGARCH models," Journal of Maliye Finans Yazllarl, vol. 23, no. 84, pp. 135-172, 2009.

[11] G. Corsetti, P. Pesenti, and N. Roubini, "Paper tigers?: A model of the Asian crisis," European Economic Review, vol. 43, no. 7, pp. 1211-1236, 1999.

[12] S. Radelet and J. Sachs, "The onset of the east asian financial crisis," in Currency Crises, P. Krugman, Eds. University of Chicago Press, 2000, pp. 105-153.

[13] R. Dornbusch, " A primer on emerging-market crises," in Preventing Currency Crises in Emerging Markets, S. Edwards and J. A. Frankel, Eds. University of Chicago Press, 2002, pp. 743-754.

[14] S. Edwards, "The end of large current account deficits, 1970-2002: Are there lessons for the United States?" National Bureau of Economic Research, Working Paper No. 11669, 2005.

[15] C. Freund, "Current account adjustment in industrial countries," Journal of International Money and Finance, vol. 24, no. 8, pp. 1278-1298, 2005.

[16] L. H. Summers, "The United States and the global adjustment process," speech at the Third Annual Stavros S. Niarchos Lecture, March 23, Washington: Institute for International Economics, 2004.

[17] E. Uygur, "The current account debate in Turkey," in Foreign Trade and Agriculture in GAP Region, E. Uygur and İ. Civcir, Eds. Discussion Paper No. 2012/25, Ankara: Turkish Economic Association, 2012.

[18] C. Freund and F. Warnock, "Current account deficits in industrial countries: The bigger they are, the harder they fall?" in G7 Current Account Imbalances: Sustainability and Adjustment, H. R. Clarida, Eds., University of Chicago Press, 2007, pp. 133-167.

[19] U. Çakmak and C. Varlık, "Sustainability of the current account deficits in the Turkish economy: An assessment in the context of the Mexican example," Journal of Economics Business and Finance, vol. 22, no. 259, pp. 114-135, 2007.

[20] I. Bunda and M. Ca' Zorzi, "Signals from housing and lending booms," Emerging Markets Review, vol. 11, no. 1, pp. 1-20, 2010.

[21] R. Arezki, V. A. Ramey, and L. Sheng, "News shocks in open economies: Evidence from giant oil discoveries (No. w20857)," National Bureau of Economic Research, 2015.

[22] M. W. Klein, "Capital account liberalization, institutional quality and economic growth: Theory and evidence," NBER Working Paper no. 11112, Cambridge, MA: National Bureau of Economic Research, 2005.
[23] D. P. Quinn and A. M. Toyoda, "Does capital account liberalization lead to growth?" Review of Financial Studies, vol. 2, no. 3, pp. 1403-1449, 2008

[24] D. Drukker, P. Gomis-Porqueras, and P. Hernandez-Verme, "Threshold Effects in the Relationship between Inflation and Growth: A new panel-data approach," Working Paper, 2005.

[25] M. S. Khan and A. S. Senhadji, "Threshold effects in the relationship between Inflation and Growth,” Technical Report, IMF Staff Papers 48, 2001.

[26] S. Kremer, A. Bick, and D. Nautz, "Inflation and growth: New evidence from a dynamic panel threshold analysis," Empirical Economics, vol. 44, no. 2, pp. 861-878, 2013.

[27] I. Akgul and S. Ozdemir, "Inflation threshold and the effects on economic growth," Journal of Economics Business and Finance, vol. 27, no. 313, pp. 85-106, 2012.

[28] B. E. Hansen, "Inference when a nuisance parameter is not identified under the null hypothesis," Econometrica: Journal of the Econometric Society, pp. 413-430, 1996.

[29] B. E. Hansen, "Threshold effects in non-dynamic panels: Estimation, testing, and inference," Journal of econometrics, vol. 93, no. 2, pp 345-368, 1999.

[30] B. E. Hansen, "Sample splitting and threshold estimation," Econometrica, pp. 575-603, 2000.

[31] H. Tong, "On a threshold model," Sijthoff and Noordhoff, vol. 29, pp. 575-586, 1978.

[32] R. S. Tsay, "Testing and modeling threshold autoregressive processes," Journal of the American Statistical Association, vol. 84, no. 405, pp. 231-240, 1989.

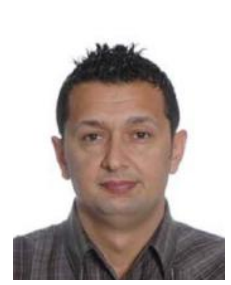

Celil Aydın was born in Istanbul, Turkey. He has received an MS degree in master of science in natura science from Stephen F. Austin State University, Nacogdoches, Texas, USA, a PhD degree in economics from Atatürk University, Erzurum, Turkey. $\mathrm{He}$ has been interested in macroeconomics and econometrics.

$\mathrm{He}$ is working as an assistant professor of Economics at Muş Alparslan University in Muş,

Turkey.

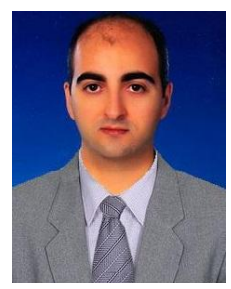

Ömer Esen was born in İstanbul, Turkey. He has received an MS degree in master of science in economics from Kocaeli University, Kocaeli, Turkey. $\mathrm{PhD}$ degree in economics from Atatürk University, Erzurum, Turkey. $\mathrm{He}$ has been interested in macroeconomics and energy economics.

$\mathrm{He}$ is working as an assistant professor of Economics at Muş Alparslan University in Muş, Turkey. 